
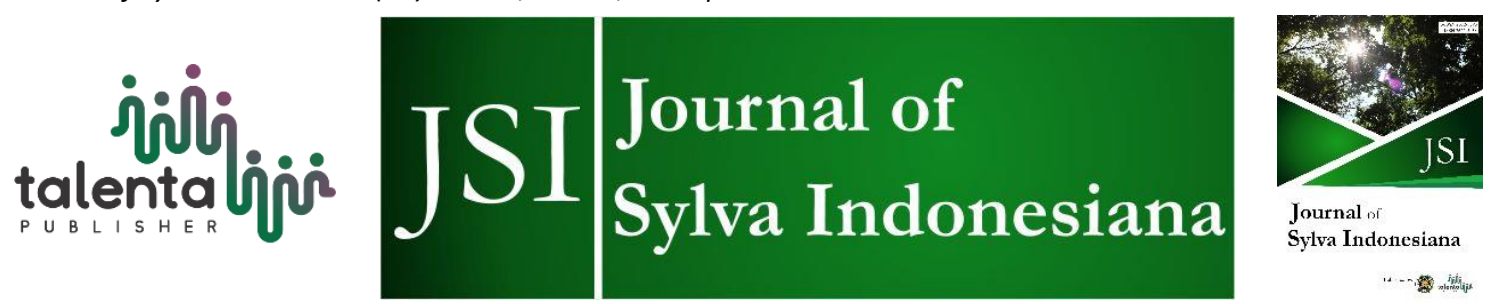

\title{
Utilization of Leaf Litter as Growth Media for Suren (Toona sureni Merr.) Rhizosphere Fungi Isolates
}

\author{
Gusmiaty $^{\left.1^{*}\right)}$, Muh. Restu' ${ }^{1}$, Siti Halimah Larekeng ${ }^{1}$, Budirman Bachtiar $^{2}$, \\ Muhammad Bima Akzad ${ }^{1}$ \\ ${ }^{1}$ Biotechnology and Tree Breeding Laboratory, Forestry Faculty of Hasanuddin University, Makassar, \\ Indonesia \\ ${ }^{2}$ Silviculture and Tree Fisiology Laboratory, Forestry Faculty of Hasanuddin University, Makassar, \\ Indonesia
}

\begin{abstract}
Leaf litter or organic matters can decompossed by microorganisms like fungi. This study aims to determine the ability of growth and the rate of decomposition of Suren (Toona sureni Merr.) rhizosphere fungi isolates on various organic media. The testing process was carried out at the Biotechnology and Tree Breeding Laboratory, Faculty of Forestry, Hasanuddin University, Makassar. The research method consisted of making fungi growing media, rejuvenating isolates and making organic media from teak leaf litter (Tectona grandis), Jabon (Anthocephalus cadamba), and Mahogany (Swietenia macrophylla). The highest growth of mycelium was found in Fusarium sp. The growth of the five best fungi isolates in the formulation of mahogany leaf litter and the highest average decomposition rate in the combination treatment of mahogany leaf litter and Fusarium sp.
\end{abstract}

Keyword: Decomposition, Rhizosphere Fungi Isolate, Leaf Litter

Received 26 September 2019 | Revised 29 October 2019| Accepted 19 November 2019

\section{Introduction}

Organic matter waste, one of which is leaf litter can decomposed by microorganisms through the decomposition process. The fallen leaves of trees produce a lot of litter and will result in environmental pollution if it not handled properly. The waste of organic material has the potential to be used as compost through a decomposition process that can support plant growth.

Decomposition is a simple process of physical and chemical change by soil microorganisms called mineralization. The term decomposition is often used to describe a large number of processes experienced by organic materials, from decomposition and destruction process of

\footnotetext{
*Corresponding author at: Biotechnology and Tree Breeding Laboratory, Forestry Faculty of Hasanuddin University, Makassar, Indonesia

E-mail address: gusmiaty@unhas.ac.id
} 
organic matter into small particles so it is available for plant nutrients and can be reabsorbed by plants [1]. Naturally, organic material wastes can decompossed by microorganisms such as bacteria and fungi. The decomposition rate process is generally influenced by the environment condition that will affect decomposer growth and decomposed material.

Decomposer microorganisms play an important role in accelerating the decomposition of organic materials process which generally containing cellulose and lignin which is known as lignocelluloses. The decomposition process of organic matter is carried out by microorganisms including bacteria, actinomycetes, yeasts, and molds which act as bioactivation agents [2]. Organic decomposer fungi generally have a better ability than bacteria to breaking down plant debris. Fungi such as Trichoderma sp, Fusarium sp, Pseudomonas, Phanerochaeta, and Thermospora are organic decomposer fungi that break down the remaining plant, especially those containing hemicellulose, cellulose, and lignin.

Research conducted by [3] has obtained 33 fungi isolates from the Suren stand rhizosphere (Toona sureni Merr.). Five of them are superior isolates that able producing high IAA and cellulase, pectinase and chitinase enzymes [4]. This research is important to evaluate the ability of those isolates to decompose organic matter and can to evaluate the effectiveness of some organic media as ingredients or growth media of Suren (Toona sureni) rhizosphere fungi.

\section{Research Methode}

This research was conducted from November 2018 to February 2019 at Biotechnology and Tree Breeding Laboratory and Integrated Laboratory of the Faculty of Forestry, Hasanuddin University, Makassar, Indonesia.

The rhizosphere fungi isolate samples were obtained from Biotechnology and Tree Breeding Laboratory of the Faculty of Forestry, Hasanuddin University. The isolates were SB 4.2, SB 5.2, SB 6.1, SB 8.1, and SB 7.1 (Table 1).

\subsection{Fungal Rejuvenation Process}

The rejuvenation process is carried out by taking 1 piece of corkborrer isolates and placed in a petri dish containing PDA media. The surface of the petri dish is heated then covered with warp plastic. Furthermore, the fungus was observed for approximately 7 days. 
Table 1 The Superior Rhizosphere Fungal Isolates

\begin{tabular}{|c|c|c|}
\hline Isolate Code & Macroscopic Image & Genus \\
\hline SB 4.2 & & Trichoderma sp. 1 \\
\hline SB 5.2 & & Trichoderma sp. 2 \\
\hline SB 6.1 & & Trichoderma sp. 3 \\
\hline SB 8.1 & & Penicillium sp. \\
\hline SB 7.1 & & Fusarium sp. \\
\hline
\end{tabular}

\subsection{Making Organic Media}

The leaf litter around mahogany stands, teak and white jabon stand were collected. After the collection process, the litter brought to the laboratory then soaked for 7 days and sun-dried for 3 days. After the dried process, the litter is crushed using a blender with a medium texture. For organic media formulations, 3 containers containing a mixture of $500 \mathrm{~g}$ each leaf litter (mahogany, teak and jabon) $50 \mathrm{~g}$ mixture of rice and bran, corn flour $50 \mathrm{~g}$, water $500 \mathrm{~mL}$, and molasses $100 \mathrm{~mL}$ were prepared. All ingredients are mixed until homogeneous. The $\mathrm{pH}$ of each media measured on 7 for each type of organic media formulation. Empty sample bottles are weighed before being filled with media. Each organic media was put into a sample bottle of $40 \mathrm{~g}$. Furthermore, the organic media formulation was sterilized using an autoclave at $121^{\circ} \mathrm{C}$ for 2 hours. The sterilization process was carried out 2 times, then, the fungus isolates were inoculated into 5 corkborrer media bottles. Media that had been inoculated with fungus isolates were incubated for 40 days.

\subsection{Observed Variable}

Observing variables is conducted once every 5 days for 8 observations, which include variables:

1. Percentage of fungal mycelium growth is calculated based on scoring [5]:

0 = Nothing 
$1=$ mycelium $\leq 25 \%$

2 = mycelium $26-50 \%$

3 = mycelium $51 \%-75 \%$

4 = mycelium $76 \%-100 \%$

2. Physical formulation of organic media such as texture, and color of organic media formulations [5]

3. The decomposition rate of organic media formulations was calculated from the reduced weight of the decomposed leaf litter weight carried out every 5 days for 40 days of observation. Estimation of the value of leaf litter decomposition rate is carried out according to the equation [6]:

$$
\begin{aligned}
& \mathrm{W}=\frac{\mathrm{W} 0-\mathrm{Wt}}{\mathrm{W} 0} \times 100 \% \\
& \text { where: } \mathrm{D}=\frac{\mathrm{W}}{\mathrm{Week} / \text { Day }}
\end{aligned}
$$

Formula description:

$$
\begin{array}{ll}
\mathrm{Xt} & =\text { Leaf litter weight after the } \mathrm{t} \text {-observation period }(\mathrm{g}) \\
\mathrm{X} 0 & =\text { Initial leaf litter weight }(\mathrm{g}) \\
\mathrm{W} & =\text { Weight loss }(\mathrm{g}) \\
\mathrm{D} & =\text { Decomposition Rate }
\end{array}
$$

\subsection{Research Design}

The research designed using a completely randomized design (CRD) factorial with 2 factors. The first factor is the fungus isolates type consisting of 5 isolates and the second factor is leaf litter type. The number of treatment combinations was 18 combinations and each treatment combination was repeated 3 times so that the total treatment was 54 treatments.

\subsection{Data analysis}

The data obtained will be analyzed descriptively and presented in the decomposition rate value diagram and analyzed using Two Ways Analysis of Variance (ANOVA).

\section{Result and Discussion}

\subsection{Percentage of Fungal Mycelium Growth}

The fungus isolates which had been rejuvenated on potato dextrose agar (PDA) were tested for growth on three types of organic media formulations namely Jabon leaf litter (Anthocephalus cadamba), Teak (Tectona grandis) and Mahogany (Swietenia macrophylla). The addition of bran, cornflour, and glucose in each type of leaf litter is as the addition of nutrients needed by 
the fungus growth. According to [7], the formula used in this study is food that contains a lot of carbohydrates such as rice, cassava, sweet potatoes, corn, molasses, and proteins such as peanuts and soybeans. Carbohydrates are the main source of energy found in the form of starch (starch) and sugars (mono and disaccharides). Sugar is used as food for fungi.

Fungal growth is characterized by the presence of mycelium which grows on organic media. Observation of fungus growth rate is done every five days for eight observations. Each media formulation has an acidity level $(\mathrm{pH})$ between 6-7. The macroscopic observation showed white mycelium that appeared on the media formulation on the fifth day after inoculation. Mycelium is a collection of several hyphae that are threads that form a stretch of the plait. According to [8], mycelial growth requires nitrogen-containing material so that extracellular protein degradation occurs to meet the needs of the fungus during growth. Mycelium growth can be characterized by the appearance of white color like cotton that grows to spread on the media surface. According to [9] the range of $\mathrm{pH}$ needed during the growth of fungal mycelium is between $\mathrm{pH}$ 4-7 which will affect growth directly on the ability of fungus cell surface to provide nutrients. The results of the percentage of fungus mycelium growth in each type of organic media formulation are presented in Figure 1.

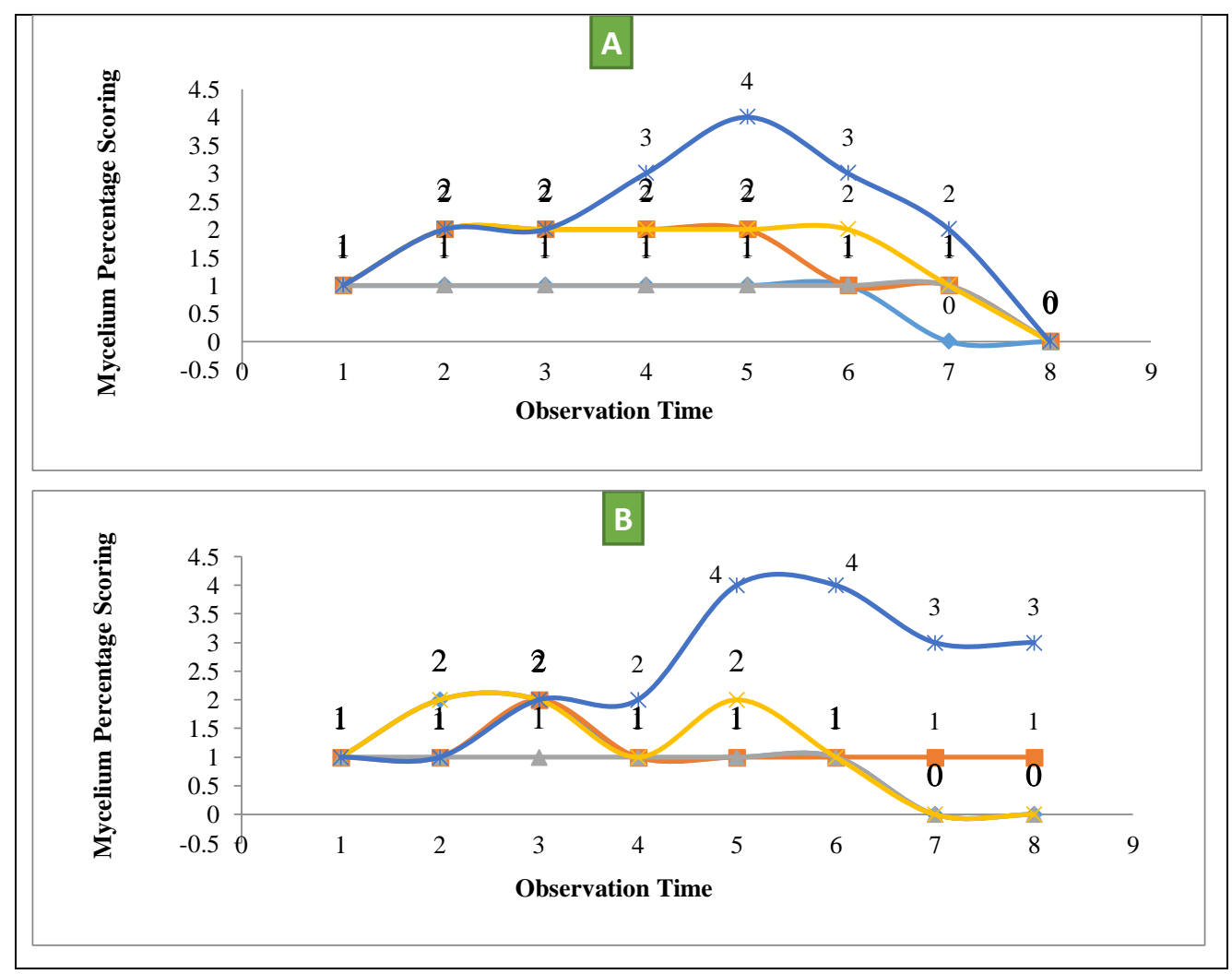




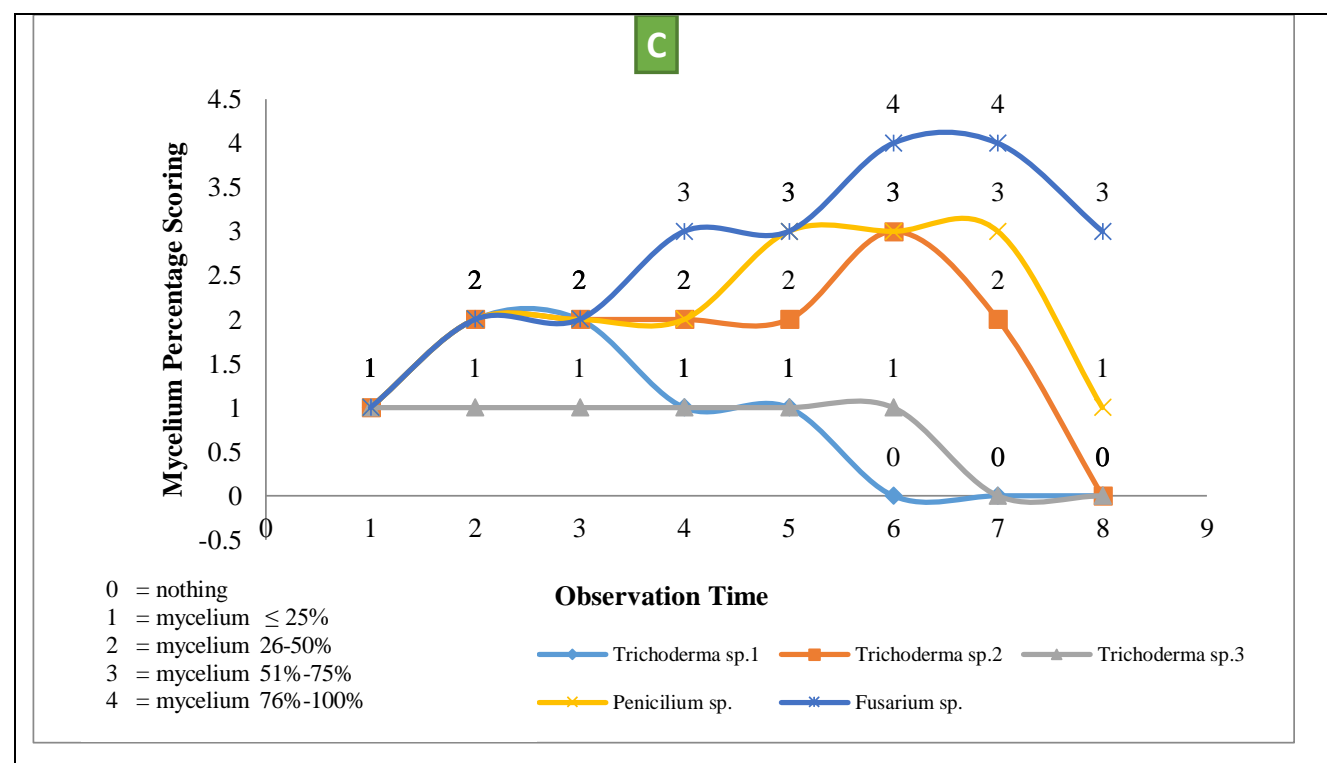

Figure 1 Growth curves percentage of superior mycelium isolates that have been inoculated in a leaf litter media formulation A: Jabon (Anthocephalus cadamba); B: Teak (Tectona grandis); C: Mahogany (Swietenia macrophylla)

Figure 1 shows that the percentage of mycelium growth of five fungi isolates at the beginning of observation was less than $25 \%$ but in the second observation until the last observation, the percentage of mycelium began to increase. Based on growth curve of mycelium fungi isolates which inoculated in Jabon leaf litter formulation (Figure 1A) showed that the highest mycelium growth produce in Fusarium sp. where the growth of mycelium continues to increase ie more than $75 \%$ or meet the Jabon leaf litter formulation, while on the sixth observation, mycelium growth begins to decline. While in Trichoderma sp.1 isolate mycelium growth remained less than $25 \%$ until the seventh observation where the mycelium showed no increase in growth. The mycelial growth rate also influences by the amount of water content in the media formulations besides the nutritional value. Generally, each type of leaf litter media formulation contains a large enough water needed for the growth of fungus mycelium. According to [10], mycelium growth in media is influenced by the nutrient's availability, and water activity influenced by the water content in media.

The fifth observation or 25 days after inoculation is the maximum growth of mycelium in each fungus isolate, it can be seen in Figure 1A that in the sixth observation is still visible, but until the eighth observation the mycelium is no longer visible or no growth. These results may be caused by the nutrient content of media for fungus isolates for growth were decreases. Growth and development of mycelium fungi isolates are influenced by nitrogen content in the substrate. The fungus mycelium cannot grow on nitrogen-deficient media, but excess nitrogen on the substrate can cause ammonia accumulation that can increase the $\mathrm{pH}$ thereby inhibiting mycelium growth [11]. 
Fusarium sp produces the highest mycelium growth percentage in Teak leaf litter formulation (Figure 1B). The growth of mycelium continues to increase by more than $75 \%$ but on the seventh observation, mycelium growth has decreased. The lowest growth of mycelium produces by Trichoderma sp. 3 isolates which are less than $25 \%$ from the beginning of observation until seventh observation even tends to decrease and mycelium did not grow.

The results of the mycelium growth of fungus isolates in Mahogany leaf litter formulation (Figure 1C) obtained the same results with Teak leaf litter media where the highest mycelium found in Fusarium sp. Growth of mycelium isolates Fusarium sp. in mahogany leaf litter continued to increase by more than $75 \%$ fulfilling leaf litter formulation until the seventh observation but decreased in eighth observation. While Trichoderma sp.3 isolate showed the lowest growth of mycelium which is less than $25 \%$ from the beginning until seventh observation. Mycelium is not visible or does not experience growth. According to [12], the lack of nitrogen in media will cause the least growth of mycelium. Other factors such as water produced by microorganisms during the composting process will be lost due to air evaporation. Therefore, wetting the compost initially during the composting process was needed [13].

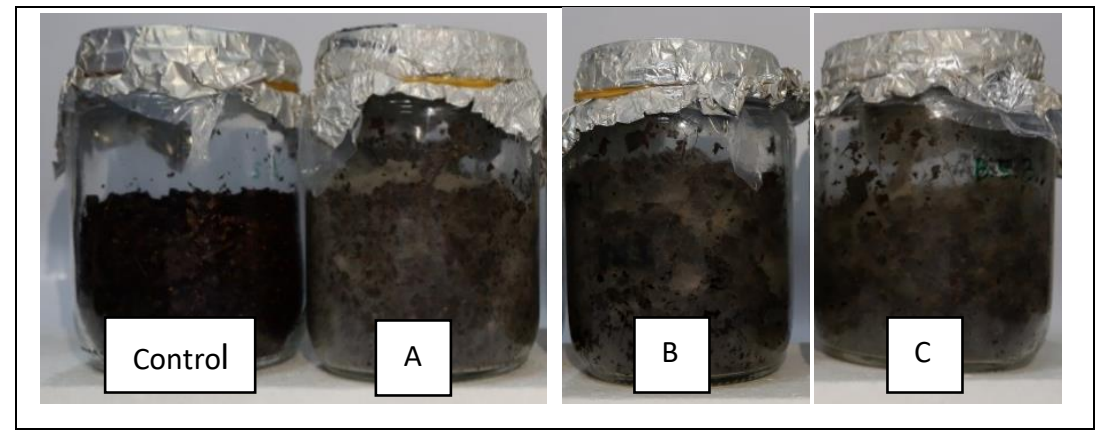

Figure 2 Jabon (A), Teak (B), and Mahogany (C) leaf litter media formulations inoculated by Fusarium sp.

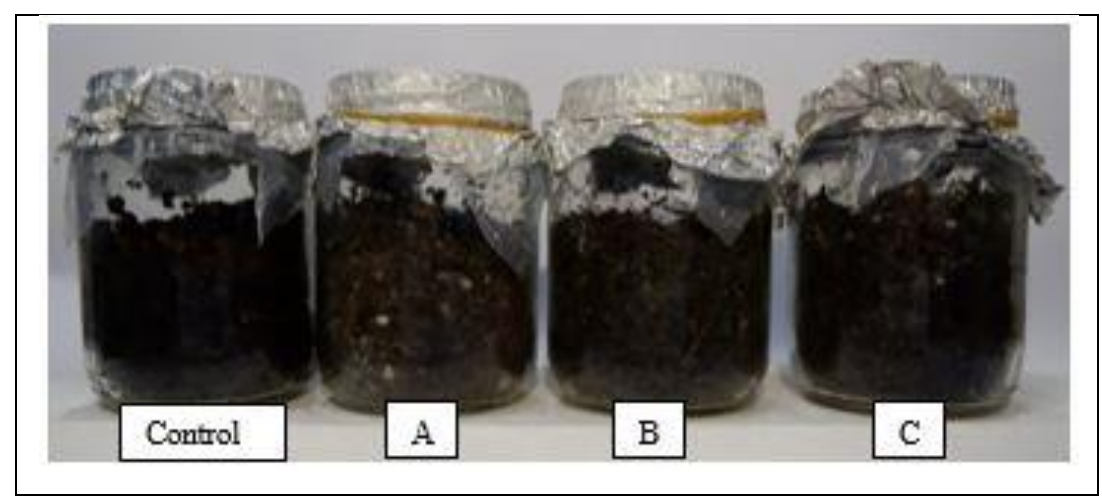

Figure 3 Jabon (A), Teak (B), and Mahogany (C) leaf litter media formulations inoculated by Tricoderma sp.3 


\subsection{Physical Observation of Organic Media Formulation}

The results of physical observations showed the differences in color and texture of each organic media formulation type. At first observation, the color and texture of each formulation were the same which is brown and rough texture, but at the end of observation, the color and texture of each formulation had changed. This is influenced by fungus activity. The color of the organic media formulation varies between brown, yellowish, whitish, blackish, and greenish. The texture is also varied, including rough, rough sticky, and slightly crumb. The difference in characteristics can be presented in Table 2 .

Table 2 Characteristics of Organic Material Formulations

\begin{tabular}{|c|c|c|c|c|c|c|}
\hline \multirow{3}{*}{ Isolate } & \multicolumn{6}{|c|}{ Characteristics of Material Formulations } \\
\hline & \multicolumn{3}{|c|}{ Color } & \multicolumn{3}{|c|}{ Texture } \\
\hline & $\begin{array}{l}\text { Jabon Leaf } \\
\text { Litter }\end{array}$ & $\begin{array}{c}\text { Teak Leaf } \\
\text { Litter }\end{array}$ & $\begin{array}{l}\text { Mahogany } \\
\text { Leaf Litter }\end{array}$ & $\begin{array}{c}\text { Jabon } \\
\text { Leaf } \\
\text { Litter } \\
\end{array}$ & $\begin{array}{c}\text { Teak } \\
\text { Leaf } \\
\text { Litter }\end{array}$ & $\begin{array}{c}\text { Mahogany } \\
\text { Leaf } \\
\text { Litter }\end{array}$ \\
\hline Control & Brownish & Brownish & Brownish & Rough & Rough & Rough \\
\hline $\begin{array}{l}\text { Trichoderma } \\
\text { sp.1 }\end{array}$ & yellowish & blackish & blackish & $\begin{array}{l}\text { crumbs a } \\
\text { little }\end{array}$ & Rough & Rough \\
\hline $\begin{array}{l}\text { Trichoderma } \\
\text { sp. } 2\end{array}$ & whitish & whitish & blackish & $\begin{array}{l}\text { crumbs a } \\
\text { little }\end{array}$ & Rough & $\begin{array}{l}\text { crumbs a } \\
\text { little }\end{array}$ \\
\hline $\begin{array}{l}\text { Trichoderma } \\
\text { sp.3 }\end{array}$ & yellowish & yellowish & blackish & $\begin{array}{l}\text { crumbs a } \\
\text { little }\end{array}$ & Rough & Rough \\
\hline Penicillium sp. & whitish & yellowish & Greenish & $\begin{array}{l}\text { crumbs a } \\
\text { little }\end{array}$ & $\begin{array}{l}\text { crumbs a } \\
\text { little }\end{array}$ & Rough \\
\hline Fusarium sp. & blackish & whitish & blackish & Rough & $\begin{array}{l}\text { rough } \\
\text { sticky }\end{array}$ & Rough \\
\hline
\end{tabular}

Based on last observations on media formulation in showed that mahogany formulations generally have the darkest color (black), except inoculation with isolates Penicillium sp. In jabon and teak litter showed variations in formulation color. The study conducted by [14] resulted that all treatments of bio activators in teak leaf litter showed a change from brownish yellow to blackish brown. The color changes occur due to the decomposition activity of composting organic material by fungus isolates. The color change is also influenced by mycelium color in the formulation. Generally, the formulation will turn blackish during the incubation period compared to the initial color, while the blackish color significantly affects the compost maturity. Good compost has a blackish brown color [15] or blackish, smelling like soil [16]. [17] also suggests that good compost is indicated by color characteristics that are different from constituent material, odorless, low moisture content, and have the same temperature as room temperature. Changes in compost physical properties can be seen by the color of compost from brownish yellow to blackish brown.

Leaf litter formulation texture testing carried out by squeezing used hand to find out the texture of each litter formulation. Jabon leaf litter that has been inoculated with fungi has a crumb 
texture to almost all isolates compared to other leaf litter that has a generally coarse texture. The difference is not so significant because previously the leaf litter had been destroyed using a shredder with a size of approximately $1 \mathrm{~mm}$. While the texture is somewhat crumbly influenced by fungi that can decompose or weathere organic's material.

\subsection{Decomposition Rate of Organic Media Formulation}

The ability of fungus isolates to decompose leaf litter can be calculating the weight of leaf litter at each observation, comparing between initial weight and final weight. Leaf litter weight slightly decreases in each observation. Because of the process of destroying organisms occurs gradually so that organic molecules are broken down into simpler forms such as carbon dioxide, water, and other mineral components [18].

Based on statistical analysis showed that isolate type had a significant influence on litter decomposition rate, it can be seen on Tukey's $r$ tests (Table 3). Based on Table 3, Fusarium sp was significantly different from Trichoderma sp.1 and Trichoderma sp.3 but not significantly different from Penicillium sp. and Trichoderma sp.2. It shows that Fusarium sp. gives a better weight reduction effect compared to other isolates.

Table 3 Tukey Advanced Test Average Decomposition Rate of Several Types of Isolates

\begin{tabular}{cc}
\hline Type of Isolate & Average \\
\hline Fusarium sp. & $0,00132^{\mathrm{a}}$ \\
Trichoderma sp. 2 & $0,00111^{\mathrm{ab}}$ \\
Penicillium sp. & $0,00095^{\mathrm{ab}}$ \\
Trichoderma sp. 1 & $0,00019^{\mathrm{b}}$ \\
Trichoderma sp. 3 & $0,00093^{\mathrm{b}}$ \\
\hline
\end{tabular}

Note: Numbers followed by the same letters show no significant difference based on the Tukey test

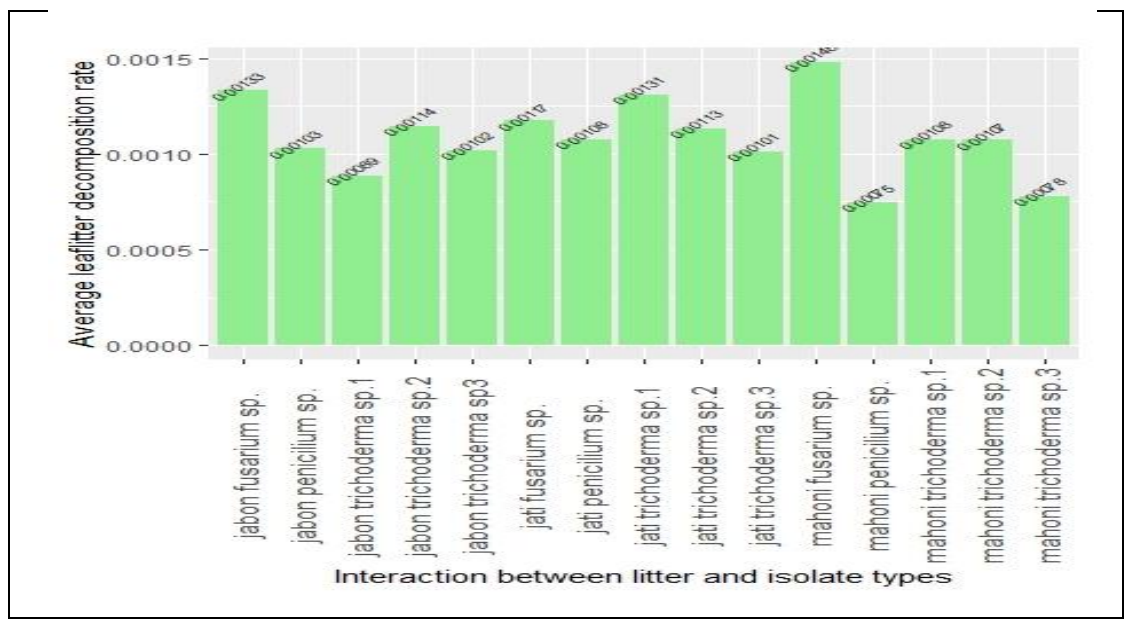

Figure 4 Average leaf litter Decomposition Rate of Interaction between Litter and Isolate Types

The average decomposition rate, a combination of mahogany leaf litter and Fusarium sp. showed the highest decomposition rate $(0.00148)$ but, a combination of Mahogany leaf litter 
with Penicillium sp produce the lowest (0.000726). The higher leaf litter decomposition means that higher fungus activity in decomposition. The decreasing of decomposition rate is caused by the organic's material that lower after fungus activities. At the beginning process, the leaf litter nutrient content and organic compounds were still quite high. Decomposition organisms can make these nutrients and organic compounds as substrates or food ingredients. According to [19], the decomposition process of material will naturally stop when limiting factors are not available or the material has been spent for the decomposition process itself.

When the nutrient content and organic compounds are decreases, the rate of decomposition also decreases. When easily decomposed organic compounds decrease and the decomposition process will also decrease. The leaf litter decomposition process involves various soil microorganisms that can recycle nutrients into the environment [20].

\section{Conclusion}

Our research found that the highest percentage of mycelium growth is found in Fusarium sp and Fusarium sp. gives a better weight reduction effect compared to other isolates. The highest average decomposition rate in the combination treatment of mahogany litter and Fusarium sp. Further research on the nutrient content of each leaf litter media formulation still needed to get a good quality biofertilizer.

\section{Acknowledgment}

The research was funded by the Ministry of Research, Technology and Higher Education through Applied Research Scheme on the fiscal year 2018.

\section{REFERENCES}

[1] R.H. Waring, and W.H. Schlesinger, Forest Ecosystem: Concept and Management, London (GB): Academic Press, Limited, 1985.

[2] Sukanto, "Making Bioactivator Agents for processing manure into Fermented Compound Organic Fertilizers," 2013. [Online]. http://bio. unsoed. ac.id/sites/default/files/Pembuatan\%20Agen\%20Bioaktivator\%20untuk\%20Pen golahan\%20Kotoran\%20Ternak\%20menjadi\%20Pupuk\%20Organik\%20majem uk\%20secara\%20Fermentasi-.pdf. [Accessed February 8, 2016].

[3] R. Y. Payangan, "Isolation of IAA (Indole Acetic Acid) Rhizosphere Fungi from Suren Community Forest Stands," Undergraduate Thesis, Faculty of Forestry, Hasanuddin University. Makassar. 2018.

[4] M. Restu, Gusmiaty, B. Bachtiar, and S.H., Larekeng, Application of Rhizosphere Microbes for Improving the Quality of Community Forest Plant Seedlings, Leading Research Reports of Higher Education, Kemenristek Dikti, 2018.

[5] I. Rahim, "Study of the Use of Weathered Fungi in the Process of Cocoa Skin Waste Decomposition and Its Application in Cocoa Seeds (Theobroma cacao L.), dissertation," Unhas Postgraduate Program, Makassar, 2015.

[6] I. Hilwan, Produksi, "Decomposition Rate and Effect of Allelopathy of Lines of Pine merkusii Jungh, et De Vriese and Acacia mangium Willd in Gunung Walat Forest, Sukabumi, West Java," Thesis, IPB Postgraduate Program, Bogor, 1993. 
[7] Y. Prayoga and T., Santoso, Viability, and Infectivity of Entomopathogenic Fungi Formulation Lecanicillium lecanii as Biopesticide Control of Riptortus Linear Chocolate Ladybug Eggs, Institut Pertanian Bogor, Bogor, 2013.

[8] L. Suharmowo, S. Budipramana, and Isnawati, "Growth of Mycelium and Body Production of White Oyster Mushroom Fruit (Pleurotus ostreatus) by Utilizing the Soybean Skin as a Mixture of Planting Media," Lentera Bio. vol. 1, no. 3, pp. 125130. 2012.

[9] Fiantiningsih, "Growth of F1 Seedling Mycelium Mushroom (Pleurotus Ostreatus) and Merang Mushroom (Volvariella volvacea) on Paddy and Long Bean Seed Media From F0 Seedlings White Sweet Potato Media," Undergraduate Thesis, Faculty of Teacher Training and Education, University of Muhammadiyah, Surakarta, 2017.

[10] S. Flora, Studying the effect of media type and incubation temperature on mycelium growth in seedling champignon (Agaricus bisporus), Undergraduate Thesis, Faculty of agricultural technology, Bogor Agricultural University, Bogor, 1986.

[11] P. Staments and J.S., Chilton, The Mushroom Cultivator, Olympia, Agaricon Press, Washington, 1983.

[12] L. Mufarrihah, "Effect of Addition of Rice bran and Tofu Dregs on Media on Growth and Production of White Oyster Mushrooms (Pleurotus ostreatus)," Undergraduate Thesis, Department of Biology, Faculty of Science and Technology, Malang State Islamic University, Malang, 2009.

[13] M. P. R., Allo, Effect of Bioactivator Type on the Decomposition Rate of Samanea Saman Rain Ki Leaves from the Unhas Campus Area, Department of Biology, Faculty of Mathematics and Natural Sciences, Hasanuddin University, Makassar. 2014.

[14] Andriany, Fahruddin, and A., Abdullah, "The Effect of Bioactivator Type on the Tectona grandis L.F. Teak Leaf Litter Decomposition Rate, in the Unhas Tamalanrea Campus Area," Jurnal Biologi Makassar, vol. 3, no. 2, pp. 31-42. 2018.

[15] R. Sutanto, Pertanian organik menuju pertanian alternatif dan berkelanjutan, Canisius Publisher, Yogyakarta, 2002.

[16] Badan Standarisasi Nasional, Spesifikasi Kompos dari Sampah Organik Domestik, SNI 19-7030-2004, Jakarta, 2004.

[17] M. Yuniwati, F., Iskarima, and A., Padulemba, "Optimization of the Conditions for the Composting Process of Organic Waste by Fermentation Using EM4," Jurnal Teknologi, vol. 5, no. 2. 2012.

[18] Y. Dawy, Wood Destructive Organisms in Wood Packaging Raw Materials and Control Efforts in the Implementation of ISPM, Bogor Agricultural University, Bogor, 2009.

[19] E. Maradhy, "Application of Mixture of Livestock Manure and Mangrove Sediment as Activator in Domestic Waste Decomposition Process," Thesis, Pascasarjana Universitas Hasanuddin, Makassar, 2009.

[20] T. Kunito and K., Nagaoka, "Effects Of Plant Litter and Addition of Nitrogen and Phosphorus on Material Community Level Physiological Profiles in Brown in A Forest Soil," Microb Environ, vol. 24, no. 1, pp. 68-71. 2009. 